\title{
The first case of septicemia due to nontoxigenic Corynebacterium diphtheriae in Poland: case report
}

\author{
Aleksandra Anna Zasada*1, Maria Zaleska ${ }^{2}$, Regina Beata Podlasin ${ }^{3}$ and \\ Ilona Seferyńska²
}

Address: ${ }^{1}$ Department of Bacteriology, National Institute of Hygiene, 24 Chocimska St., 00-791 Warsaw, Poland, ${ }^{2}$ Laboratory of Microbiology, Institute of Haematology and Blood Transfusion, 5 Chocimska St., 00-957 Warsaw, Poland and ${ }^{3}$ Hospital of Infection Disease, 37 Wolska St., 01 201 Warsaw, Poland

Email: Aleksandra Anna Zasada* - azasada@pzh.gov.pl; Maria Zaleska - azasada@pzh.gov.pl; Regina Beata Podlasin - reginabp@wp.pl; Ilona Seferyńska - iseferynska@wp.pl

* Corresponding author

\section{Published: 05 May 2005}

Annals of Clinical Microbiology and Antimicrobials 2005, 4:8 doi:10.1 I86/I476-07| I-4-8

This article is available from: http://www.ann-clinmicrob.com/content/4/I/8

(c) 2005 Zasada et al; licensee BioMed Central Ltd.

This is an Open Access article distributed under the terms of the Creative Commons Attribution License (http://creativecommons.org/licenses/by/2.0), which permits unrestricted use, distribution, and reproduction in any medium, provided the original work is properly cited.
Received: 15 March 2005

Accepted: 05 May 2005

\begin{abstract}
Background: Toxigenic strains of Corynebacterium diphtheriae are well known agent of diphtheria. Nontoxigenic strains can cause atypical course of the disease. Invasive diseases caused by $C$. diphtheriae occur very rare.

Case presentation: We have described the first case of septicemia and endocarditis due to nontoxigenic $C$. diphtheriae biotype gravis in Poland. The patient has not belonged to any group of risk such infection.

Conclusion: The case presented in this article shows unusual case of infection connected with nontoxigenic $C$. diphtheriae that took place in the area where have been no cases of diphtheria and other $C$. diphtheriae infections for near ten years. It shows the importance of identifying Corynebacterium isolates at the species level especially when the strain has been isolated from normally sterile sites.
\end{abstract}

\section{Background}

Corynebacterium diphtheriae is well known as an agent of localized respiratory tract disease potentially complicated by systemic effects of exotoxin [1,2]. It is also able to cause cutaneous and wound infections. But nontoxigenic strains can produce atypical manifestations of disease. They are able to cause diseases such as mild diphtheria-like pharyngitis, cutaneous infections, septic arthritis, abscesses, septicemia and endocarditis [3-14]. The pathogenesis of infection caused by nontoxigenic $C$. diphtheriae is unknown.
We have described the first case of bacteremia and endocarditis due to nontoxigenic $C$. diphtheriae var. gravis in Poland. Since 1996 there was no cases of $C$. diphtheriae infections in Poland area.

\section{Case presentation}

In January 2004 previously healthy 38 -year-old man was admitted to hospital with fever $\left(40^{\circ} \mathrm{C}\right)$ and arthralgia of upper and lower extremities. He was not addicted to drugs or alcohol. He smoked about 20 cigarettes per day. Physical examination revealed mild tachycardia with normal cardiac sounds and normal blood pressure. Oral cavity examination showed poor dentition. He presented gener- 
alized arthralgia and edema and redness of involved joints. Also there was a 3 day history of papulomacular haemorrhagic rash on his lower extremities. The patient had no symptoms of respiratory tract infection and X-ray examination showed no evidence of pneumonia. Laboratory evaluation revealed elevated white blood cell count $\left(17,8 \times 10^{3} / \mu \mathrm{l}\right)$ with $34 \%$ of band neutrophils and $51 \%$ of granulocytes, decreased platelet count $\left(29 \times 10^{3} / \mu \mathrm{l}\right)$, slightly elevated liver enzymes (AST $52 \mathrm{U} / \mathrm{L}$, ALT $41 \mathrm{U} / \mathrm{L}$, LDH 589 U/L, alkaline phosphate $150 \mathrm{U} / \mathrm{L}$ ), hyperbilirubinemia $(2,69 \mathrm{mg} \%)$, elevetad creatinine concentration $(1,51 \mathrm{mg} \%)$, mild proteinuria, leucocyturia and erythrocyturia. The initial diagnosis was septicemia. Three blood samples were drawn during two first days of hospitalization for microbiological evaluation and empirical therapy with ceftazidime and teicoplanin was started.

Nontoxigenic C. diphtheriae biotype gravis was isolated from all blood cultures. On the third day of treatment the antibiotics were changed to amikacin and ciprofloxacin according to antibiogram. Despite resolution of most symptoms and negative blood and throat swab cultures after eight days of treatment the patient was still febrile. For that reason ciprofloxacin was changed to clindamycin.

Transthoracic and transoesopharyngeal echocardiography performed on the 13th day of treatment showed two vegetations attached to the mitral and aortal valves. The patient underwent surgery for replacement of both valves. The cultures from vegetations were negative. After the operation the patient recovered. Although the cultures were negative we have supposed that the vegetations were caused by $C$. diphtheriae because the patient had no cardiac troubles before bacteremia.

Nontoxigenic C. diphtheriae biotype gravis isolated from blood cultures was identified and biotyped with use of morphological and biochemical methods as described elsewhere. Toxin production was examined in vitro by the conventional [1] and modified Elek test [15]. Polymerase chain reaction (PCR) was used for the detection of diphtheria toxin gene $[1,16]$ and the PCR result was negative.

The susceptibility of isolates to 13 antibiotics was determined by the disk diffusion method accordingly to the National Committee for Clinical Laboratory Standards [17] guidelines on Mueller-Hinton II blood agar (supplemented with $5 \%$ sheep blood). However NCCLS does not define breakpoints for Corynebacterium sp. For that reason interpretation was done comparatively as for Streptococcus spp. and Staphylococcus spp., because some breakpoints are different for that genera. The antimicrobial disks contained penicillin, cefaclor, cefuroxime axetil, cefazolin, ceftazidime, ceftriaxone, cefepime, amikacin, meropenem, azithromycin, trimethoprim-sulfamethoxazole, vancomycin and teicoplanin. Determination of MIC (results are shown in brackets) for ampicillin $(0.5 \mathrm{mg} / \mathrm{L})$, gentamicin $(0.38 \mathrm{mg} / \mathrm{L})$, ciprofloxacin $(0.125 \mathrm{mg} / \mathrm{L})$, clindamycin $(0.25 \mathrm{mg} / \mathrm{L})$, erythromycin $(0.016 \mathrm{mg} / \mathrm{L})$, chloramphenicol $(2 \mathrm{mg} / \mathrm{L})$ and tetracycline $(0.5 \mathrm{mg} / \mathrm{L})$ was done using E-test strips. Clindamycin and erythromycin MIC breakpoints for Streptococcus spp. are lower than for Staphylococcus spp. but both interpretations showed susceptibility of examined C. diphtheriae strain. Ampicillin MIC breakpoints pointed to investigated strain as ampicillin resistant. The strain was also resistant to penicillin and ceftazidime and intermediate to cefuroxime axetil and ceftriaxone.

\section{Conclusion}

C. diphtheriae causes systemic disease sporadically. Only 58 cases of bacteremia infections due to that microorganism were described between 1893 and 2003 [3-9]. Forty four of them were caused by nontoxigenic strains. There has been no information of bacteremia of such etiology in Poland. In previously described cases infections were connected with low socioeconomic group of people. Most of them were intravenous drug users, alcohol addicts, unemployed and homelesses $[4,7-12,18,19]$. Our patient does not belong to any of above mentioned risk groups. It is supposed that the predominant route for bacterial contamination and penetration into the bloodstream are various skin lesions such as cutaneous ulcers, bullous pemphigoid, scabies and open fractures $[9,12,18,19]$. But in the case described here no connection between bacteremia and skin lesions was found. We have supposed that mass dental caries enabled bacteria penetration into the bloodstream.

The strain isolated from the patient was resistant to penicillin and third generation cephalosporins. Penicillin G, erythromycin or amoxicillin is the reference treatment for C. diphtheriae infections $[1,13,20]$ but resistance to these antibiotics was reported $[1,13,14]$. Our results are also in agreement with the observation of Patey et al. [7] that appreciable resistance to third generation cephalosporins exists among $C$. diphtheriae strains.

Diphtheria is still endemic in Eastern Europe and other regions of the world although it has virtually disappeared in developed countries following mass immunization in the 1940s. Current vaccine against diphtheria contains the toxoid so it protects only against the toxigenicity but not the invasiveness of $C$. diphtheriae [9]. The high rate of immunization with diphtheria toxoid may place selective pressure on the microorganism to develop other patogenicity factors. The bacterium could acquire exogenous DNA such as transposons, bacteriophages DNA or plasmids that contains single virulence genes or whole pathogenicity islands. 
Nontoxigenic C. diphtheriae can produce atypical manifestations of disease. The pathogenesis of infection caused by nontoxigenic strains of $C$. diphtheriae is unknown and requires investigation. The organism is capable of tissue invasion and causing fulminant disease and appears to have a predilection for cardiac valvular endothelium and synovium [8]. The occurrence of joint involvement connected with bacteremia due to $C$. diphtheriae was also reported $[7,8]$.

The case presented in this article and cases described in other papers show the importance of identifying Corynebacterium isolates from normally sterile sites at the species level. Determination of antimicrobial susceptibility has also fundamental role in success of treatment because resistance to some antimicrobial agents has been reported in $C$. diphtheriae $[1,13,14]$. It is worth to underlined that infections connected with $C$. diphtheriae can occur in immunized population.

\section{Competing interests}

The author(s) declare that they have no competing interests.

\section{Authors' contributions}

AAZ carried out molecular and phenotypic tests of toxigenicity and participated in identification and antimicrobial susceptibility tests and drafted the manuscript, $\mathrm{MZ}$ participated in identification and antimicrobial susceptibility tests and helped to draft the manuscript, RBP and IS participated in diagnosis, observation and treatment of the case and helped to draft the manuscript.

All authors read and approved the final manuscript.

\section{Acknowledgements}

We thank Dr Piotr Litwinski and Dr Jan Chejbowicz from Department of Cardiosurgery, Institute of Cardiology, Warsaw for their surgical cooperation.

\section{References}

I. Efstratiou A, Maple C: Diphitheria. Manual for the laboratory diagnosis of diphtheria. Copenhagen: WHO; 1994.

2. Murphy JR: Corynebacterium diphtheriae. In Medical Microbiology 4th edition. Edited by: Baron S. Galveston: University of Texas Medical Branch; 1996:413-422.

3. Estratiou A, Tiley M, Sangrador A, Greenacre E, Cookson BD, Chen SCA, Mallon R, Gilbert GL: Invasive disease caused by multiple clones of Corynebacterium diphtheriae. Clin Infect Dis 1993, I7:136.

4. Huber-Schneider C, Gubler J, Knoblauch M: Endocarditis due to Corynebacterium diphtheriae cause by contact with intravenous drugs: report of $\mathbf{5}$ cases. Schweiz Med Wochenschr 1994, | 24:2173-2| 80 .

5. Isaac-Renton JL, Boyko WJ, Chan R, Crichton E: Corynebacterium diphtheriae septicemia. Am J Clin Pathol I98I, 75:631-634.

6. Lortholary O, Buu-Hoi A, Gutmann L, Acar J: Corynebacterium diphtheriae endocarditis in France. Clin Infect Dis 1993, 1 7:1072-1074.

7. Patey O, Bimet F, Emond JP, Estrangin E, Riegel Ph, Halioua B, Dellion $S$, Kiredjian M: Antibiotic susceptibilities of 38 non-toxigenic strains of Corynebacterium diphtheriae. I Antimicrob Chemother 1995, 36: I I08-III0.

8. Tiley SM, Kociuba KR, Heron LG, Munro R: Infective endocarditis due to nontoxigenic Corynebacterium diphtheriae: report of seven cases and review. Clin Infect Dis 1993, I 6:27 I-275.

9. Trepeta RW, Edberg SC: Corynebacterium diphtheriae endocarditis: sustained potential of a classical pathogen. Am J Clin Pathol 1984, 8 1:679-683.

10. Barakett V, Morel G, Lesage D, Petit JC: Septic arthritis due to a Nontoxigenic strain of Corynebacterium diphtheriae subspecies mitis. Clin Infect Dis 1993, I 7:520-52I.

II. Funke G, Altwegg M, Frommelt L, von Graevenitz A: Emergrnce of related nontoxigenic Corynebacterium diphtheriae biotype mitis strains in Western Europe. Emerg Infect Dis 1999, 5:477-480.

12. Gruner E, Opravil M, Altwegg M, von Graevenitz A: Nontoxigenic Corynebacterium diphtheriae isolated from intravenous drug users. Clin Infect Dis 1994, I 8:94-96.

13. Wilson APR: Treatment of infection caused by toxigenic and non-toxigenic strains of Corynebacterium diphtheriae. J Antimicrob Chemother 1995, 35:717-720.

14. von Hunolstein C, Scopetti F, Efstratiou A, Engler K: Penicillin tolerance amongst non-toxigenic Corynebacterium diphtheriae isolated from cases of pharyngitis. J Antimicrob Chemother 2002, 50:125-128.

15. Engler KH, Glushkevich T, Mazurova IM, George RC, Efstratiou A: A modified Elek test for detection of toxigenic corynebacteria in the diagnostic laboratory. J Clin Microbiol 1997, 35:495-498.

16. Pallen MJ, Hay AJ, Puckey LH, Efstratiou A: Polymerase chain reaction for screening clinical isolates of corynebacteria for the production of diphtheria toxin. J Clin Pathol 1994, 47:353-356.

17. NCCLS: Performance standards for antimicrobial disk susceptibility tests; Approved standard. In Document M2-A8 8th edition. NCCLS: USA; 2003.

18. Harnisch JP, Tronca E, Nolan CM, Turck M, Holmes KK: Diphtheria among alcoholic urban adults. Ann Intern Med I 989, I I I:7 I-82.

19. Zuber PLF, Grunder E, Altwegg M, von Graevenitz A: Invasive infection with non-toxigenic Corynebacterium diphtheriae among drug users. Lancet 1992, 339:1359.

20. Farizo KM, Strebel PM, Chen RT, Kimbler A, Clearly TJ, Cochi SL: Fatal respiratory disease due to Corynebacterium diphtheriae : case report and review of guidelines for management, investigation and control. Clin Infect Dis 1993, I 6:59-68.

\section{Publish with Biomed Central and every scientist can read your work free of charge}

"BioMed Central will be the most significant development for disseminating the results of biomedical research in our lifetime. "

Sir Paul Nurse, Cancer Research UK

Your research papers will be:

- available free of charge to the entire biomedical community

- peer reviewed and published immediately upon acceptance

- cited in PubMed and archived on PubMed Central

- yours - you keep the copyright

Submit your manuscript here:

http://www.biomedcentral.com/info/publishing_adv.asp 